\title{
Caracterização do solo utilizado em alvenaria de taipa e adobe para restauração do patrimônio histórico
}

O casarão tombado popularmente conhecido como Casa de Bem Bem, localizado na região do Centro Histórico de Cuiabá/MT, sofreu consecutivos desabamentos devido às más condições de preservação, onde as águas pluviais causaram danos às alvenarias de adobe e de taipa. Foram realizadas contenções em caráter emergencial para evitar maiores danos e autorizadas obras de restauro de toda a edificação. Assim, surge este trabalho com o objetivo de verificar a compatibilidade entre o solo utilizado originalmente para execução das alvenarias de adobe e de taipa e do terreno natural do casarão a ser possivelmente utilizado para atender a demanda de novo material para o restauro juntamente com a viabilidade de reutilização do material desabado. Foram realizados os ensaios de caracterização física das amostras coletadas de adobe, de taipa e do terreno natural: análise granulométrica, determinação dos limites de Atterberg, determinação da massa específica e absorção de água; e determinação do teor de acidez. Verificou-se grande semelhança entre os três materiais coletados, apresentando curvas granulométricas simétricas, massas específicas e limites de Atterberg de valores aproximados, sendo este último indicando ainda boas condições para emprego na execução de novas alvenarias para o patrimônio histórico, tanto do terreno natural quanto do reaproveitamento do material desabado.

Palavras-chave: Casa de Bem Bem; Tijolo de adobe; Alvenaria de taipa.

\section{Characterization of the soil used in taipa and adobe masonry for the restoration of historical heritage}

\begin{abstract}
The listed house as national historic heritage popularly known as Casa de Bem Bem, placed in the region of the Historic Center of Cuiabá/MT, suffered successive landslides due to poor conservation conditions, where rainwater caused damage to the mudbrick wall and rammed earth masonry. Emergency actions were taken to prevent further damage and authorized the restoration of the entire building. Thus, this research has the objective of verifying the compatibility between the soil originally used for the execution of mudbrick wall and rammed earth masonry, and the natural terrain of the edification to be possibly used to meet the demand for new material for the restoration along with the feasibility of reusing collapsed material. Physical characterization tests were performed on samples collected from mudbrick, mud and natural terrain: granulometric analysis, determination of Atterberg limits, determination of specific mass and water absorption; and determination of the acidity content. There was a great similarity between the three materials collected, with symmetrical granulometric variations, specific masses and Atterberg limits of approximated values, the last indicator still showing good conditions for use in the execution of new mudbrick walls and rammed earth masonry for the historical heritage, using the new source of natural terrain and reusing collapsed material.
\end{abstract}

Keywords: Casa de Bem Bem; Mudbrick wall; Rammed earth masonry.

Topic: Engenharia Civil

Reviewed anonymously in the process of blind peer.
Received: 09/08/2020

Approved: 20/11/2020
Marcos de Oliveira Valin Junior (D)

Instituto Federal de Mato Grosso, Brasil http://lattes.cnpq.br/1988817143994600 http://orcid.org/0000-0003-2961-2011 marcos.valin@cba.ifmt.edu.br

Ilço Ribeiro Junior (iD)

Instituto Federal de Mato Grosso, Brasil http://lattes.cnpq.br/8383617965831103

http://orcid.org/0000-0002-2850-5612

ilco.ribeiro@cba.ifmt.edu.br

Francisco Eduardo Macedo Saraiva (iD

Universidade Federal de Mato Grosso, Brasil

http://lattes.cnpq.br/8244342157318897

http://orcid.org/0000-0003-4292-6656

francisco.eduardo.1996@gmail.com

\author{
Nayara Andrade de Souza (D) \\ Instituto Federal de Mato Grosso, Brasil \\ http://lattes.cnpq.br/6497001112274253 \\ http://orcid.org/0000-0003-4915-4679 \\ nayarag3andrade@gmail.com
}

Referencing this:

VALIN JUNIOR, M. O.; RIBEIRO JUNIOR, I.; SARAIVA, F. E. M.; SOUZA, N. A.. Caracterização do solo utilizado em alvenaria de taipa e adobe para restauração do patrimônio histórico. Engineering Sciences, v.8, n.3, p.19-38, 2020. DOI: http://doi.org/10.6008/CBPC23183055.2020.003.0003 


\section{INTRODUÇÃO}

Desde muito cedo a humanidade já despertou curiosidade sobre sua história antepassada, buscando respostas para inúmeras perguntas. Esta curiosidade levou muitas pessoas a dedicarem sua vida reconstruindo a história a partir de fragmentos que atravessaram o tempo em forma de monumentos, por exemplo. Contudo, constatou-se que estes monumentos ainda assim eram suscetíveis as degradações naturais e surge então uma preocupação em conservar e até mesmo restaurar estes patrimônios históricos.

Torna-se ainda mais sensível à degradação quando se trata de patrimônios mais antigos, que devido a sua idade foram concebidos através de técnicas rudimentares, e merecem uma atenção especial na sua conservação, como é o caso do casarão tombado conhecido popularmente como a Casa de Bem Bem, construída por volta de 1850, na região do centro de Cuiabá/MT, empregando as artes vernaculares do adobe e da taipa de pilão, muito características da época, e ostentando os valores da arquitetura colonial.

A residência foi construída por volta de 1850 e, portanto, possui mais de um século e meio de idade (STEIN, 2018). Sua estética ostenta os valores da arquitetura colonial, um estilo comum em cidades históricas brasileiras, presente no país desde o início do domínio português e com forte influência da arquitetura europeia, mesclando a utilização dos sistemas de taipa de pilão e tijolos de adobe.

O conjunto do Centro Histórico de Cuiabá, formado por cerca de 400 imóveis tombados, faz parte do Patrimônio Histórico e Cultural e tem amparo em leis de conservação. Contudo, alguns destes imóveis encontram-se em situação crítica, como é o caso da 'Casa de Bem Bem', que sofreu dois desabamentos nos anos de 2017 e 2018 , devido a chuvas intensas.

Para reverter esta situação foram autorizadas obras de restauração em caráter emergencial. Com isto surge a oportunidade do estudo aqui proposto, caracterizando o solo empregado na execução das alvenarias de taipa e adobe e possibilitando posterior busca por melhor opção de solo para restauração, sendo o reaproveitamento do mesmo ou o emprego de um solo de mesmas características geotécnicas.

A edificação aqui estudada foi consagrada em nome de sua moradora Dona Bem Bem e possui uma história expressiva e representa em si a tradição do modo de viver e cultura cuiabanos, onde foi centralizado o tradicional festejo de São Benedito. Contudo, após uma série de intervenções malsucedidas o casarão sofreu dois desabamentos recentemente, resultado do comprometimento das alvenarias de terra crua pelo contato direto com águas pluviais.

Para reverter esta situação, foram autorizadas obras emergenciais de cobertura e contenção, bem como posterior restauração completa da edificação. Para este processo, será necessária a execução de novas alvenarias de adobe e de taipa, de forma mais semelhante possível à original. Surge então a oportunidade desta pesquisa, buscando determinar qual a matéria prima mais indicada a ser utilizada para este processo, ou seja, qual solo apresenta as características do solo utilizado na concepção da edificação.

A hipótese inicial se baseia na possível similaridade do solo local, em que se encontra o patrimônio histórico tombado, uma vez que o sistema construtivo da taipa e do adobe costumam utilizar a terra crua do próprio terreno em que é construído, devido a abundância local e simplicidade na questão de logística. Caso 
não se confirme esta hipótese inicial após comparação dos resultados de ensaios de caracterização, seguese com a hipótese de que o solo originalmente utilizado foi coletado próximo à região da edificação em questão. Consoante as buscas pelo solo compatível, também se sustenta a hipótese de reutilização, mesmo que parcial, do material da alvenaria existente que se encontra desmoronada, ainda que este não atenda a toda demanda.

O objetivo geral consiste na verificação da compatibilidade entre o solo aplicado na construção de alvenarias de taipa e adobe de uma edificação que compõe o patrimônio histórico do Centro Histórico de Cuiabá, que se encontra em estado de desmoronamento, e o solo do terreno natural da edificação para ser utilizado em sua restauração. Os objetivos específicos são: Analisar a compatibilidade das amostras do solo utilizado na execução da alvenaria de taipa e adobe da edificação e do terreno natural da edificação; Analisar a possibilidade de reutilização do material das alvenarias desmoronadas.

\section{MATERIAIS E MÉTODOS}

O presente trabalho apresenta um estudo de caso, no qual será caracterizado fisicamente o solo utilizado na execução das alvenarias de taipa e adobe, a fim de colaborar com os trabalhos de restauração da edificação. A metodologia para o desenvolvimento desta, além do levantamento bibliográfico acerca do sistema construtivo da taipa e do adobe, será dividida em duas etapas. Estas etapas são apresentadas detalhadamente a seguir.

\section{Caracterização das amostras}

Após a devida autorização da empresa responsável pela restauração do imóvel, foi realizada uma visita à obra da Casa de Bem Bem para observação das atuais condições do patrimônio histórico, registro fotográfico e coleta do material das alvenarias de taipa e adobe em questão e amostra do terreno natural. Para a coleta do material da taipa foram utilizadas as ferramentas enxada e pá de bico para colocar o material em saco de ráfia, conforme observa-se na Figura 1a, e o ponto de coleta na Figura 1b. Já para a coleta do material da alvenaria de adobe necessitou-se apenas de um saco de ráfia, Figura 2a, uma vez que os tijolos de adobe encontravam-se dispersos, conforme observa-se na Figura $2 \mathrm{~b}$. Devido aos desabamentos e interferências de obras realizadas anteriormente no local, buscou-se um ponto em que as amostras nas quais características originais tenham se mantido mais preservadas possíveis, ou seja, sem presença de materiais que não fazem parte do solo utilizado na alvenaria original.

Semelhante à coleta da taipa, para a amostra do terreno natural foram utilizados enxada, pá de bico e saco de ráfia. $O$ ponto de coleta escolhido foi um monte resultante da escavação de valas de cerca de 50 $\mathrm{cm}$ de profundidade ao longo do terreno (Figura 3). Antes de sua coleta, o material foi homogeneizado. Os pontos de coleta da taipa, adobe e terreno natural estão representados na planta baixa da Figura 4 pelos marcadores 1,2 e 3, respectivamente. 


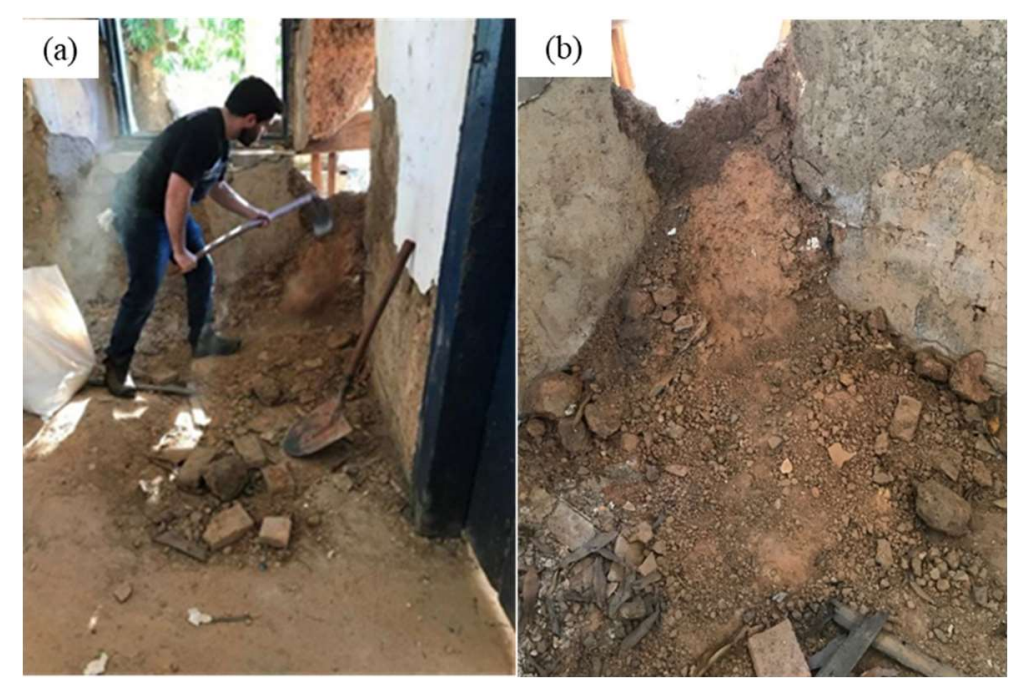

Figura 1: Coleta do material da alvenaria de taipa (a) e local de coleta da amostra de taipa (b).

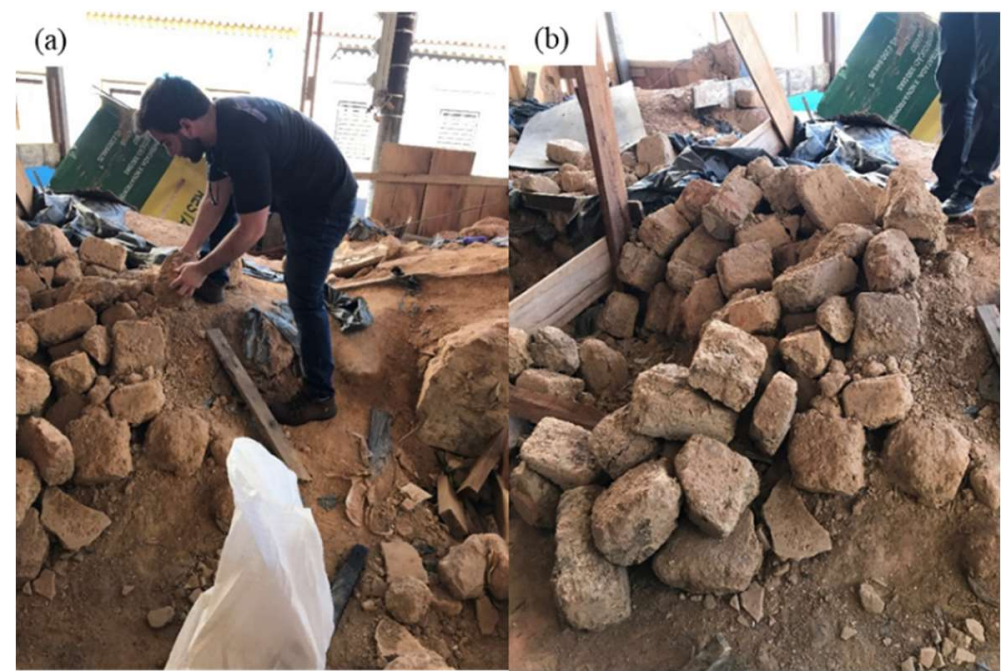

Figura 2: Coleta do material da alvenaria de adobe (a) e local de coleta da amostra de adobe (b).

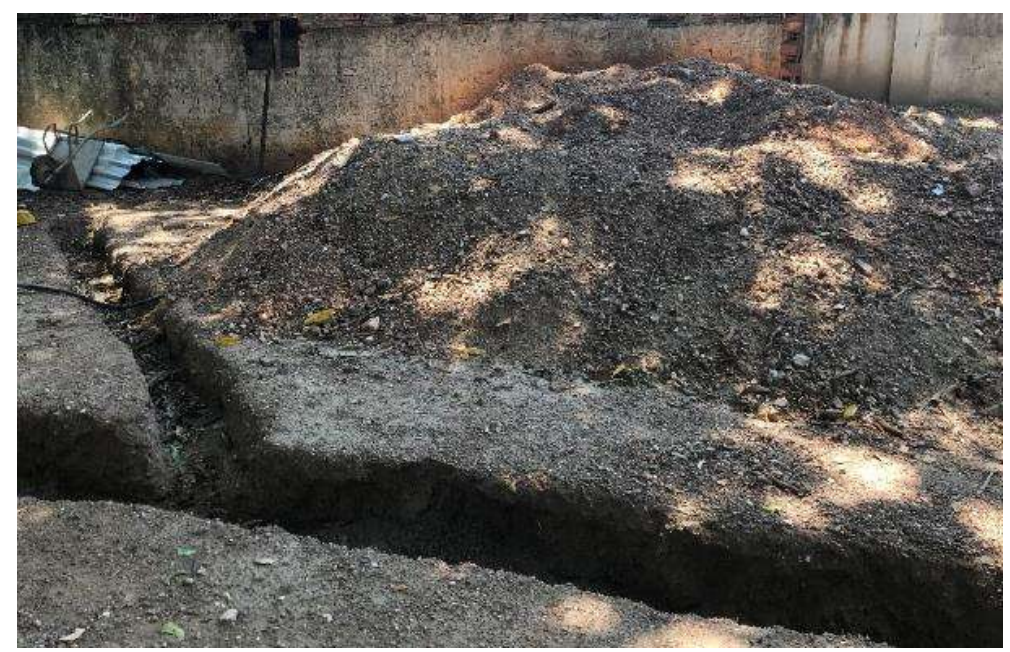

Figura 3: Ponto de coleta da amostra do terreno natural.

Realizada a coleta, os materiais foram transportados e armazenados em sacos plásticos transparentes, para se evitar a perda da porção de material fino, no Laboratório de Solos do DACC/IFMT Campus Cuiabá Cel. Octayde Jorge da Silva, onde também foram realizados todos ensaios de caracterização, descritos a seguir, segundo as normas regulamentadoras. 


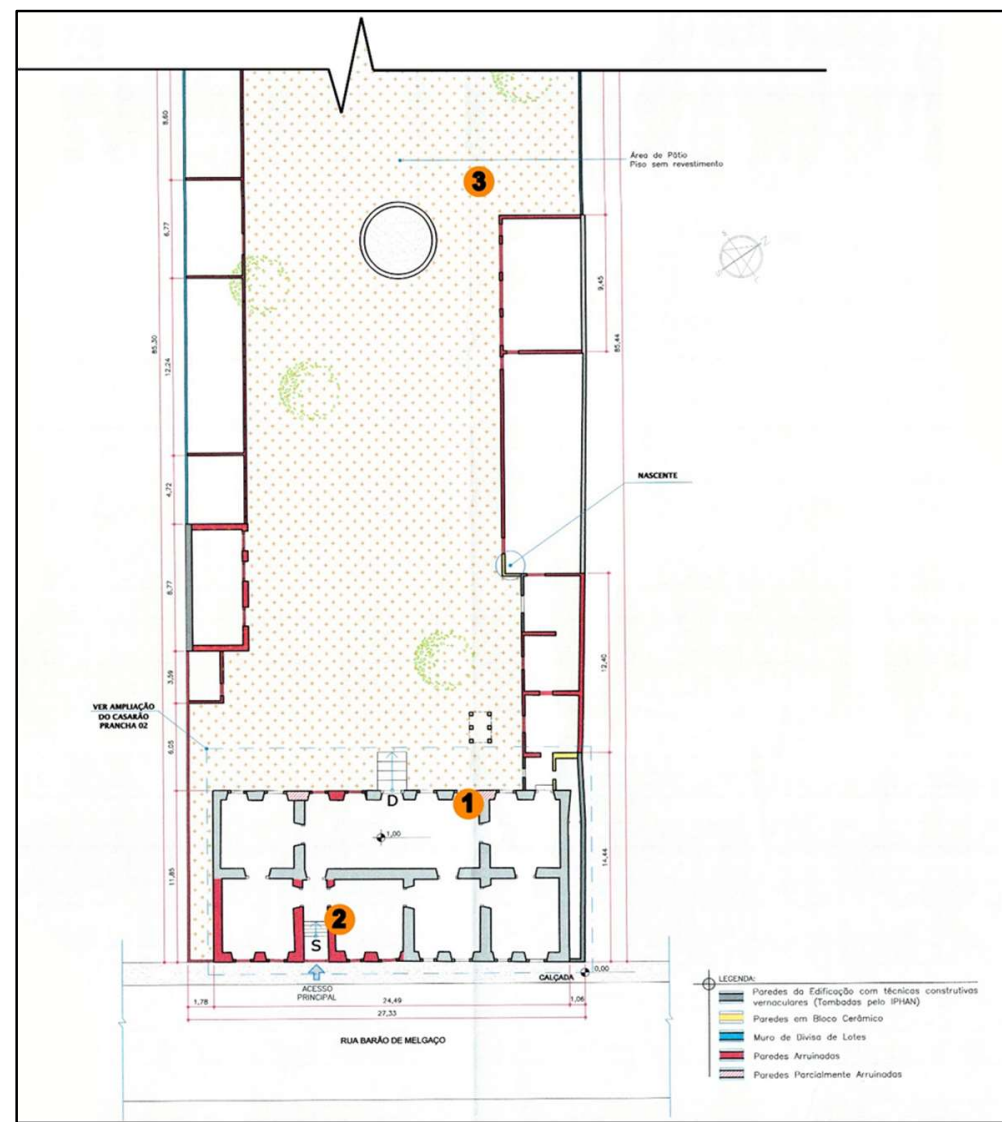

Figura 4: Planta baixa da Casa de Bem Bem com os pontos de coleta das amostras. Fonte: Adaptado de Secretaria de Cultura, Esporte e Turismo de Cuiabá (2020).

\section{Preparação das amostras}

As amostras de adobe, de taipa e do terreno natural coletadas foram preparadas conforme recomenda a NBR 6457 (ABNT, 2016), utilizando o processo com secagem prévia ao ar livre até atingirem a umidade higroscópica, uma vez que o solo em questão visivelmente apresenta partículas maiores que inviabilizam o processo com umidade natural.

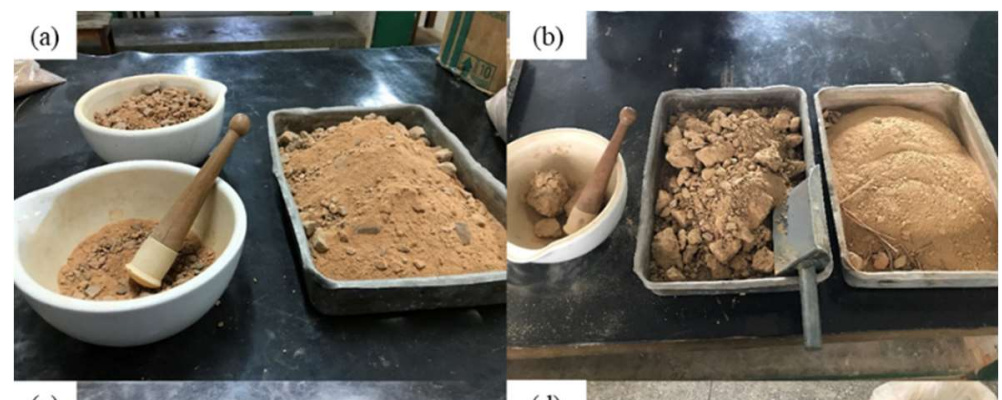

(c)

(d)

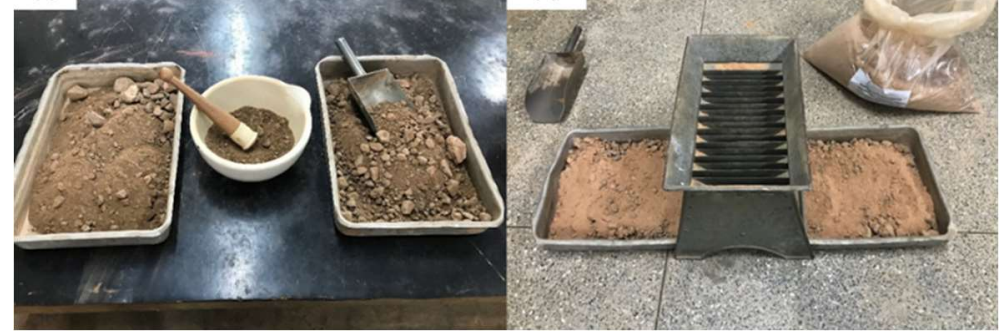

Figura 5: Destorroamento do material coletado da alvenaria de taipa (a), de adobe (b) e do terreno natural (c); repartidor de amostras (d).

Foi necessário desmanchar os torrões, tanto do material da taipa como do adobe, conforme Figura 
$5 a, 5 b$ e $5 c$, respectivamente, com mão de gral e almofariz, tomando o cuidado de não destruir os agregados e homogeneizar as amostras. Foi necessário cominuir o tijolo de adobe previamente com o auxílio de um martelo, aplicando golpes leves para se evitar grandes deformações, apenas fraturando o objeto. Por fim as amostras foram quarteadas, com o emprego de um repartidor de amostras (Figura 5d), até se obter uma quantidade representativa suficiente para execução de cada ensaio de caracterização.

\section{Análise granulométrica}

Conforme a preparação da amostra recomendada pela NBR 6457 (ABNT, 2016), as amostras secas e destorroadas de adobe, de taipa e do terreno natural foram passadas na peneira de $76 \mathrm{~mm}$, separadamente, e o material retido poderia ser descartado, contudo não houve material retido. Do passante, foi separada a quantidade de cerca de $4.000 \mathrm{~g}$, conforme recomendação da norma quanto as dimensões dos grãos maiores observados visualmente, enquadrando-se no intervalo entre 5 e $25 \mathrm{~mm}$, e massa anotada como MT.

Adotando como referência para o ensaio de granulometria a NBR 7181 (ABNT, 2016), as amostras foram separadas em parte passante e parte retida na peneira de 2,00 $\mathrm{mm}$, lavando-se a parte retida com água potável (Figura 6a), ainda na mesma peneira de 2,00 mm, para eliminar todo material fino que estava aderido aos grãos maiores e seca em estufa por 24 horas. Este material foi utilizado no peneiramento grosso.

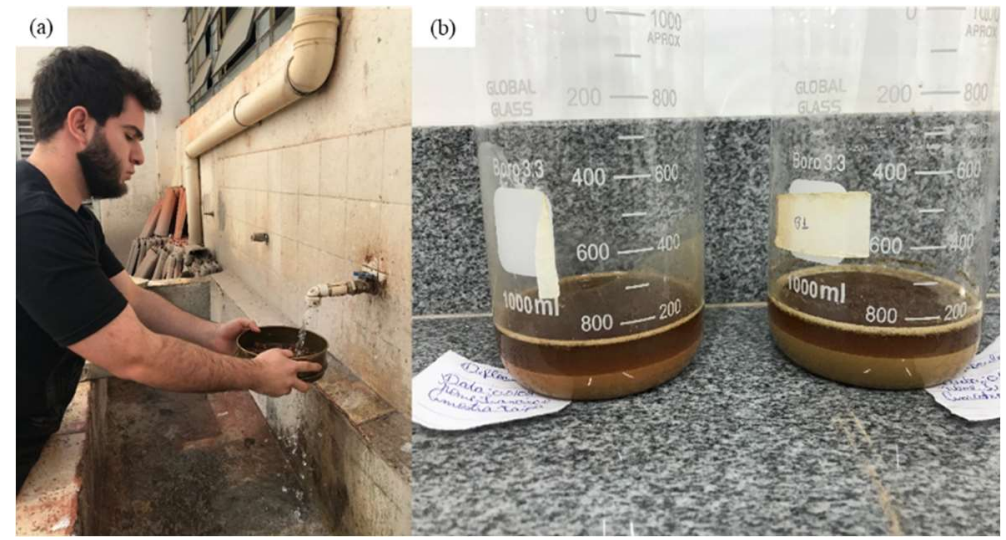

Figura 6: Lavagem do material retido na peneira de 2,00 $\mathrm{mm}$ (a) e amostras submersas em defloculante (b).

Do material passante, tomou-se cerca de $70 \mathrm{~g}$ de cada amostra, para o processo de sedimentação, registrando suas massas como $\mathrm{Mw}$ e transferindo-os cada um para seu respectivo béquer com defloculante (125 cm $\mathrm{cm}^{3}$ de solução de hexametafosfato de sódio com a concentração de $45,7 \mathrm{~g}$ do sal por $1.000 \mathrm{~cm}^{3}$ de solução), por 12 h (Figura 6b). Foram tomadas ainda três amostras de cada material, com cerca de $30 \mathrm{~g}$, para determinação da umidade higroscópica (w), de acordo com o Anexo A da NBR 6457 (ABNT, 2016).

Decorrido o tempo mínimo dos materiais submersos na solução defloculante para sedimentação, estes foram transferidos para o copo de dispersão (Figura 7a) e submetidos cada um a 15 minutos de ação do aparelho de dispersão. Então foram transferidos mais uma vez, para uma proveta (Figura 7b), lavando o copo de dispersão com jato de água destilada de uma pisseta para evitar a perda de material aderente nas paredes, preenchendo até a marca de $1000 \mathrm{~cm}^{3}$ e agitada vigorosamente por 1 minuto com auxílio de uma haste de agitação (Figura 8a), diferenciando-se um pouco da NBR 7181 (ABNT, 2016). Logo em seguida 
iniciaram-se as medidas com densímetro e termômetro, sendo realizadas nos intervalos (t) indicados pela norma: 0,5 min, 1 min, 2 min, 4 min, 8 min, 15 min e 30 min e 1 h, 2 h, 4 h, 8 h, e 24 h, sendo o densímetro e o termômetro retirados da suspensão após cada leitura a partir da terceira. Realizada a última leitura, os materiais foram vertidos e lavados na peneira de $0,075 \mathrm{~mm}$, em seguida levados à estufa por $24 \mathrm{~h}$ e reservados para o peneiramento fino.

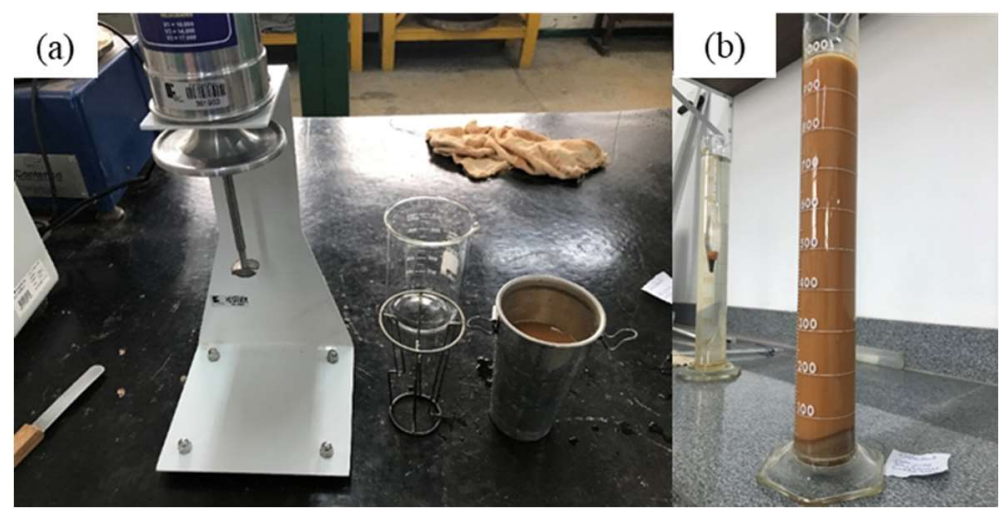

Figura 7: Aparelho de dispersão, copo de dispersão com amostra de adobe (a) e proveta com amostra de taipa em processo de sedimentação (b).

A parte final do ensaio consiste no peneiramento da parte fina e da parte grossa, separadamente, utilizando as peneiras de série normal indicadas na norma para cada material e agitador mecânico, anotandose a massa retida em cada uma destas.

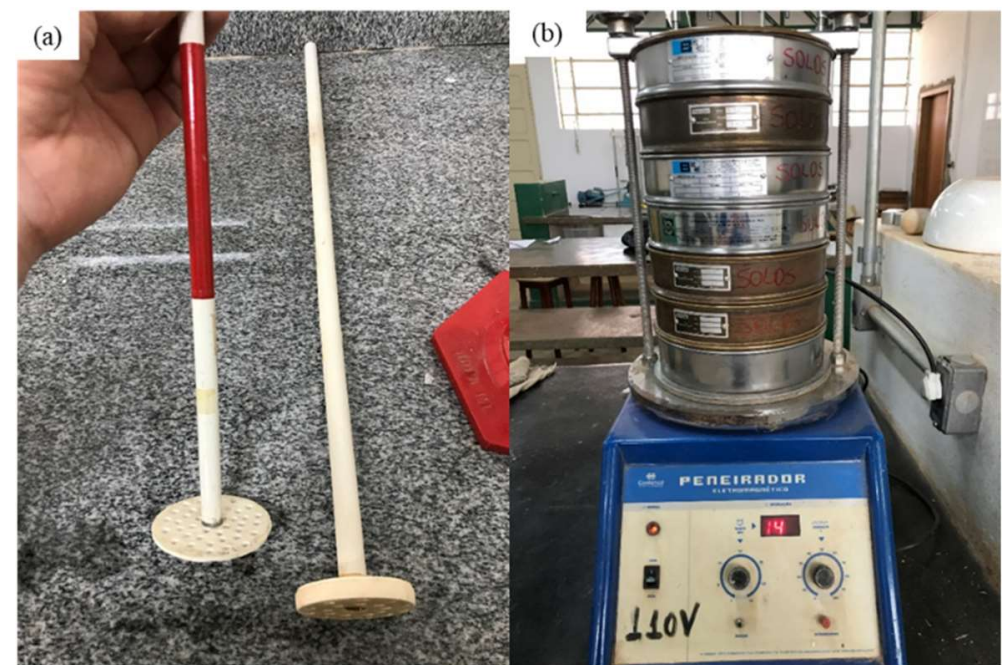

Figura 8: Haste de agitação (a) e peneiramento grosso da taipa em agitador mecânico (b).

Para o peneiramento fino foram utilizadas as peneiras de $1,2 \mathrm{~mm}, 0,6 \mathrm{~mm}, 0,42 \mathrm{~mm}, 0,25 \mathrm{~mm}, 0,15$ $\mathrm{mm}, 0,075 \mathrm{~mm}$ e o fundo, sendo submetido a ação do agitador mecânico por $15 \mathrm{~min}$. Para o peneiramento grosso, sua massa inicial foi determinada e anotada como $\mathrm{Mg}$ foram utilizadas as peneiras $50 \mathrm{~mm}, 38 \mathrm{~mm}$, $25 \mathrm{~mm}, 19 \mathrm{~mm}, 9,5 \mathrm{~mm}$ e 4,8 $\mathrm{mm}$ e o fundo. 0 jogo de peneiras também foi submetido a $15 \mathrm{~min}$ no agitador mecânico (Figura 8b).

A partir dos dados obtidos, segue-se uma série de cálculos. Para determinação da massa total da amostra seca (Ms), utiliza-se a Equação 1: 


$$
M_{s}=\frac{\left(M_{T}-M_{g}\right)}{(100+w)} \times 100+M_{g}
$$

Onde:

Ms é a massa total da amostra seca; MT é a massa da amostra seca em temperatura ambiente; $\mathrm{Mg}$ é a massa do material seco retido na peneira de $2,0 \mathrm{~mm}$; w: é a umidade higroscópica do material passado na peneira de 2,0 $\mathrm{mm}$. As porcentagens de material passante nas peneiras de $50 \mathrm{~mm}, 38 \mathrm{~mm}, 25 \mathrm{~mm}, 19 \mathrm{~mm}, 9,5 \mathrm{~mm}, 4,8$ mm e 2,0 mm são calculadas a partir da Equação 2, sendo aplicada para cada peneira.

$$
Q_{g}=\frac{\left(M_{s}-M_{r}\right)}{M_{s}} \times 10
$$

Onde:

Qg: é a porcentagem de material passado em cada peneira; Ms: é a massa total da amostra seca; Mr: é a massa do material retido acumulado em cada peneira.

Para análise dos dados obtidos na sedimentação, determina-se a porcentagem de material em suspensão correspondente a cada leitura no densímetro, utilizando-se a Equação 3.

$$
Q_{s}=N \times \frac{\rho_{s}}{\left(\rho_{s}-\rho_{m d}\right)} \times \frac{V \times \rho_{w c}\left(L-L_{d}\right)}{\frac{M_{w}}{(100+w)} \times 100}
$$

Em que:

V: é o volume da proveta igual a $1000 \mathrm{~cm} 3$;

Qs: é a porcentagem de solo em suspensão no instante da leitura do densímetro; $\mathrm{N}$ : é a porcentagem de material que passa na peneira de $2,0 \mathrm{~mm}(\mathrm{Qg})$, calculado conforme a formula anterior; ps: é a massa específica dos grãos do solo, expressa em gramas por centímetro cúbico $\left(\mathrm{g} / \mathrm{cm}^{3}\right)$; pmd: é a massa específica do meio dispersor na temperatura de calibração do densímetro $\left(20^{\circ} \mathrm{C}\right)$, expresso em gramas por centímetro cúbico $\left(\mathrm{g} / \mathrm{cm}^{3}\right)$; pwc: é a massa específica da água na temperatura de calibração do densímetro $\left(20^{\circ} \mathrm{C}\right)$, utilizando o valor de 1,000

$\mathrm{g} / \mathrm{cm}^{3}$;

L: é a leitura do densímetro na suspensão; Ld: é a leitura do densímetro no meio dispersor, na mesma temperatura da suspensão; Mw: é a massa do material úmido submetido à sedimentação, expressa em gramas (g); w: é a umidade higroscópica do material passado na peneira de $2,0 \mathrm{~mm}$.

O diâmetro máximo das partículas em suspensão de cada leitura realizada no densímetro pode ser calculado pelo método gráfico de Casagrande ou através da lei de Strokes, expressa pela Equação 4. Para este estudo foi adotado o segundo método, assim como a norma também indica.

$$
d=\sqrt{\frac{1800 \times \mu}{\rho_{s}-\rho_{m d}} \times \frac{z}{t}}
$$

Em que:

d: é o diâmetro máximo das partículas, expresso em milímetros (mm); $\mu$ : é o coeficiente de viscosidade do meio dispersor, no caso deste ensaio a água, à temperatura de ensaio, em $\mathrm{g} x$ $\mathrm{s} / \mathrm{cm}^{2}$. Este coeficiente é obtido através da Tabela 2 disponível na NBR 7181 (ABNT, 2016); z: é a altura de queda das partículas, com resolução de $0,1 \mathrm{~cm}$, correspondente à leitura do densímetro, expressa em centímetros $(\mathrm{cm})$;

t: é o tempo de sedimentação, expresso em segundos (s); ps: é a massa específica dos grãos do solo, determinada de acordo com o Anexo B da NBR 6458 (ABNT, 2016), método executado e descrito no item 4.2.6, expressa em gramas por centímetro cúbico $\left(\mathrm{g} / \mathrm{cm}^{3}\right)$; рmd: é a massa específica do meio dispersor, à temperatura de ensaio, expressa em gramas por centímetro cúbico $\left(\mathrm{g} / \mathrm{cm}^{3}\right)$. Para efeitos de cálculo a norma adotada recomenda utilizar o valor de $1,000 \mathrm{~g} / \mathrm{cm}^{3}$. 
As porcentagens de material fino passante em cada peneira, de aberturas $1,2 \mathrm{~mm}, 0,6 \mathrm{~mm}, 0,42 \mathrm{~mm}$, $0,25 \mathrm{~mm}, 0,15 \mathrm{~mm}$ e 0,075 mm, são calculadas pela Equação 5 .

$$
Q_{f}=\frac{M_{w} \times 100-M_{r}(100+w)}{M_{w} \times 100} \times N
$$

Onde:

Mw: é a massa do material úmido submetido ao peneiramento fino ou à sedimentação, conforme o ensaio tenha sido realizado apenas por peneiramento ou por combinação de sedimentação e peneiramento, respectivamente; w: é a umidade hidroscópica do material passado na peneira de $2,0 \mathrm{~mm}$; Mr: é a massa do material retido acumulado em cada peneira; $\mathrm{N}$ : é a porcentagem de material que passa na peneira de $2,0 \mathrm{~mm}(\mathrm{Qg})$.

\section{Determinação do teor de umidade de solos}

Os procedimentos para determinação do teor de umidade de solos estão descritos no Anexo A da NBR 6457 (ABNT, 2016). De forma simplificada, o ensaio consiste em comparar a massa inicial de uma pequena amostra, cerca de 30 gramas para o caso de solos argilosos como os utilizados na taipa e adobe em estudo, em uma cápsula e sua massa após secar em estufa por cerca de 24 h. Através dessa comparação podemos concluir qual era a massa referente à umidade. $\mathrm{O}$ teor de umidade pode ser calculado pela Equação 6.

$$
w=\frac{M_{1}-M_{2}}{M_{2}-M_{3}} \times 100
$$

Em que:

w: é o teor de umidade, expresso em porcentagem (\%); $\mathrm{M} 1$ : é a massa do solo úmido mais a massa do recipiente, expressa em gramas (g); $\mathrm{M} 2$ : é a massa do solo seco mais a massa do recipiente, expressa em gramas (g); M3: é a massa do recipiente (cápsula metálica com tampa ou par de vidro de relógio com grampo), expressa em gramas (g).

\section{Determinação do teor de umidade de solos}

Para este ensaio, as amostras de adobe, de taipa e do terreno natural foram preparadas conforme a NBR 6457 (ABNT, 2016), descrito em 3.1.1, então foram peneiradas na peneira de 0,42 mm até se obter cerca de $200 \mathrm{~g}$ de material passante de cada um.

A execução do ensaio obedeceu a NBR 6459 (ABNT, 2016). Antes de iniciar o ensaio, foi realizada a verificação e regulagem do aparelho de Casagrande conforme instruções em norma.

Tomou-se metade da amostra preparada e, em uma cápsula de porcelana, acrescentou-se água em pequenos incrementos, homogeneizando a amostra, até obter uma consistência em que fossem necessários cerca de 35 golpes para fechar a ranhura no ensaio. Esta avaliação visual e tátil depende da experiência do técnico. Ao obtê-la, a amostra foi transferida para a concha do aparelho de Casagrande uma pequena porção, com o auxílio de uma espátula, e moldando-a conforme ilustração na referida norma regulamentadora. Em seguida, realizou-se a abertura da ranhura na parte central com o cinzel, também ilustrado em norma.

Iniciou-se então a sequência de golpes ao acionar cuidadosamente a alavanca do aparelho de Casagrande, em velocidade constante, até as paredes da ranhura se unirem novamente por uma extensão 
de aproximadamente $13 \mathrm{~mm}$ de comprimento e registrando a quantidade de golpes. Imediatamente foi coletada uma pequena parte do material ao longo da porção que se uniu, porção ilustrada na Figura 9, e transferida para uma cápsula, na qual foram registradas sua massa inicial e após $24 \mathrm{~h}$ em estufa para determinação do teor de umidade conforme descrito no Anexo A da NBR 6457 (ABNT, 2016), também descrito no item 3.1.3.

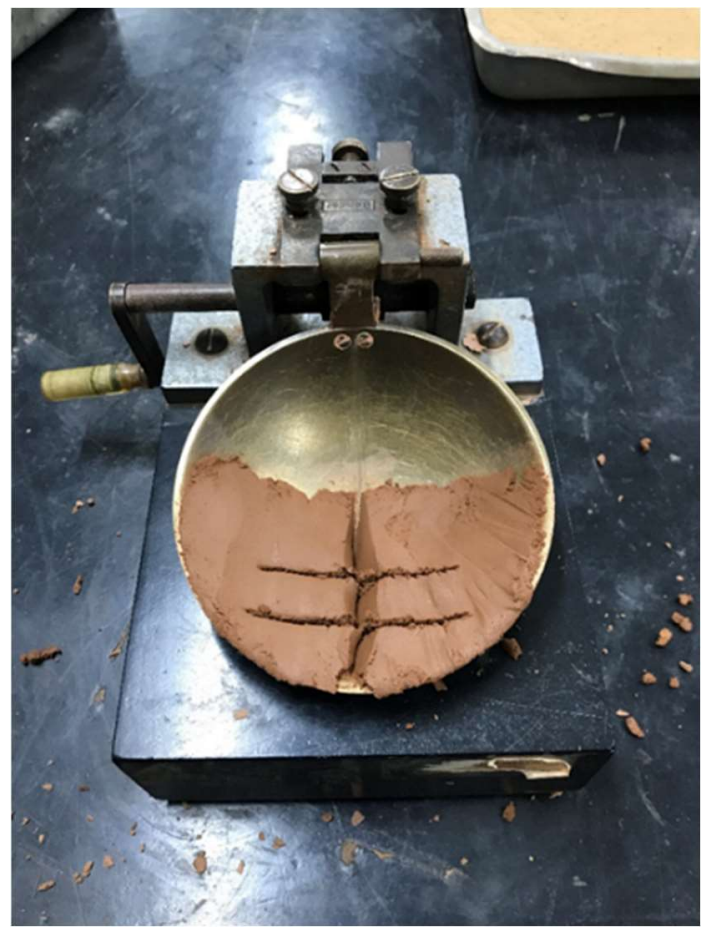

Figura 9: Corte para coletar porção da ranhura que se uniu após ensaio com aparelho de Casagrande.

O material restante na concha do aparelho foi retornado à cápsula de porcelana, acrescido de mais água e homogeneizado por 3 minutos. Repetiu-se o processo descrito acima para se obter 5 pontos, onde a cada novo ponto foram necessários uma menor quantidade de golpes, uma vez que a amostra estava mais úmida.

O resultado é expresso em forma de um gráfico no qual as ordenadas apresentam os números de golpes e as abscissas os teores de umidade correspondentes, traçando uma reta ajustada pelos pontos obtidos. O limite de liquidez (WL) do solo corresponde ao teor de umidade aos 25 golpes.

\section{Determinação do limite de plasticidade}

Para determinação do limite de plasticidade, as amostras utilizadas correspondem a outra metade do material passante na peneira de 0,42 mm preparado conforme a NBR 6457 (ABNT, 2016), para o ensaio de determinação de limite de liquidez, conforme descrito em 3.1.1 e 3.1.4.

Este ensaio se iniciou com a adição de água à amostra em uma cápsula de porcelana e homogeneização de 15 minutos. Em seguida, foi moldada uma pequena bola com as mãos e então rolada sobre a placa de vidro com superfície esmerilhada, pressionando levemente com a palma da mão a fim de dar um formato cilíndrico. Espera-se que este fragmente-se ao atingir um diâmetro de $3 \mathrm{~mm}$, facilmente comparado com a haste de gabarito. Durante o ensaio, o cilindro fragmentou-se antes de atingir o diâmetro 
normatizado, foi então adicionado água à amostra, homogeneizada e novamente moldada. Este processo se repetiu algumas vezes até se obter sucesso. Caso o cilindro tivesse se fragmentado um diâmetro menor ao gabarito, este deveria ser apenas homogeneizado, para perder umidade e novamente moldado.

Quando o cilindro se rompeu conforme o esperado (Figura 10), foi coletado um tamanho da ordem de 100 mm em uma cápsula e sua massa aferida naquele momento e após 24 horas na estufa, obtendo-se o teor de umidade deste conforme o Anexo A da NBR 6457 (ABNT, 2016), também descrito no item 3.1.3. 0 processo foi repetido para a obtenção de três valores de teor de umidade.

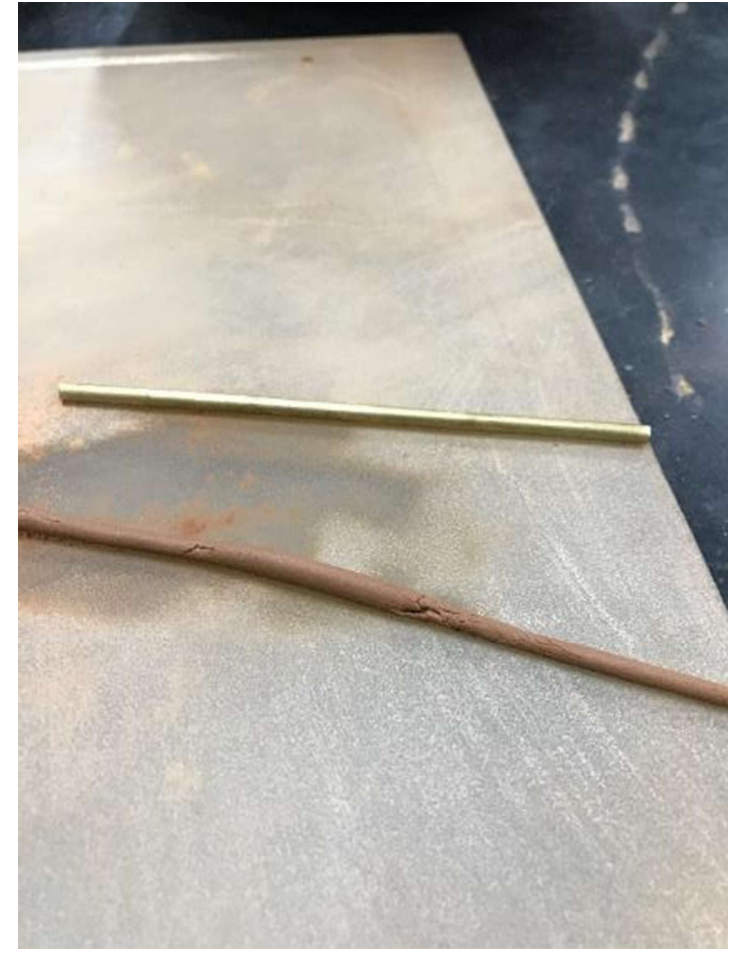

Figura 10: Ensaio de Limite de Plasticidade.

O limite de plasticidade (WP) é dado pela média dos três valores de teor de umidade, sendo inválido caso algum deles apresente variação maior que 5\% quanto à média. $O$ índice de plasticidade (IP) do solo é obtido ao subtrair os valores WP de WL, obtido no item 3.1.4.

\section{Determinação da massa específica e da absorção de água}

Para a realização deste ensaio, as amostras também foram preparadas conforme a NBR 64571 (ABNT, 2016), onde as amostradas foram separadas em duas porções, cada uma, pelo peneiramento na peneira de 4,8 mm. Para o material passante a norma recomendou a utilização de cerca de 500 g. Já para o material retido foram utilizados $2.000 \mathrm{~g}$, sendo lavado na própria peneira de $4,8 \mathrm{~mm}$, a fim de eliminar todo material fino aderente.

Para determinação da massa especifica e da absorção de água, tanto da parte mais fina quanto da mais grossa, foi adotada a norma NBR 6458 (ABNT, 2016). Esta atualização da norma substitui sua versão de 1984 e também a norma NBR 6508 (ABNT, 1984), sendo esta norma agora contemplada no Anexo B da NBR 6458 (ABNT, 2016), mantendo-se o mesmo procedimento. 
O material retido e lavado na peneira $4,8 \mathrm{~mm}$ foi dividido em duas amostras de massas aproximadamente iguais e em seguida submersos em água destilada (Figura 11) por um período de 24 horas, a fim de levar os grãos à saturação. Por exigência da norma o ensaio é executado em duas amostras e seu resultado expresso pela média destes. Decorrido o prazo, as amostras foram retiradas da água e secas com auxílio de um pano umedecido, até se obter amostras saturadas com superfície seca. As massas das amostras foram anotadas como Msat.

A próxima etapa consistiu na determinação da massa das amostras submersas em água destilada (Mi), através da balança hidrostática e de um cesto de tela, e da temperatura da água (T). Após retiradas da água, as amostras foram levadas à estufa por $24 \mathrm{~h}$, para eliminar a água presente até se atingir massa constante. A massa seca foi registrada como Ms.

(a)

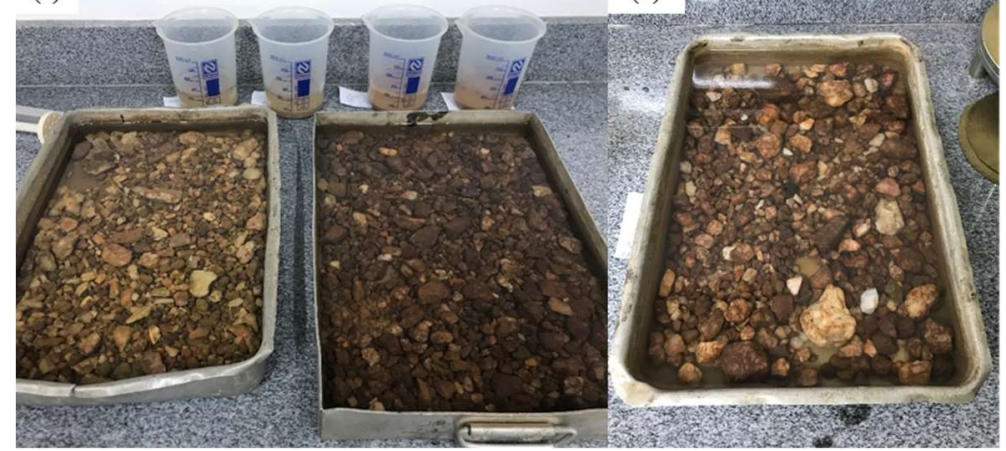

Figura 11: Amostras de taipa e adobe, retidas a frente e passantes ao fundo na peneira de $4,8 \mathrm{~mm}$, submersas em água destilada (a) e amostra do terreno natural submersa em água destilada (b).

A massa específica aparente dos grãos (que inclui os vazios permeáveis e impermeáveis, e exclui os vazios entre os grãos), a massa específica dos grãos (que inclui os vazios impermeáveis e exclui os vazios permeáveis e os vazios entre os grãos) e a absorção de água são calculados a partir das Equações 7, 8 e 9, respectivamente.

$$
\begin{aligned}
& \rho_{s}=\frac{M_{s}}{M_{s}-M_{i}} \times \rho_{w} \\
& \rho_{a p(s)}=\frac{M_{s}}{M_{s a t}-M_{i}} \times \rho_{w} \\
& A_{a}=\frac{M_{s a t}-M_{s}}{M_{s}} \times 100
\end{aligned}
$$

Onde:

ps: é a massa específica dos grãos, expressa em gramas por centímetro cúbico $\left(\mathrm{g} / \mathrm{cm}^{3}\right)$; $\rho a p(s)$ : é a massa específica aparente dos grãos 2, expressa em gramas por centímetro cúbico $\left(\mathrm{g} / \mathrm{cm}^{3}\right)$; Aa: é a absorção de água, em porcentagem da massa de material seco;

Ms: é a massa da amostra seca;

Msat: é a massa da amostra saturada, superficialmente seca;

Mi: é a massa da amostra totalmente imersa em água destilada; $\rho w$ : é a massa específica da água à temperatura T do ensaio, de acordo com a Tabela A.1 disponível no Anexo $A$ da NBR 6458 (ABNT, 2016).

As amostras passantes na peneira de $4,8 \mathrm{~mm}$ também foram divididas em duas amostras. De cada amostra homogeneizada, foi coletada uma quantidade tal que a massa seca esteja em torno de 50 g e 
registrada como M1. As amostras foram então colocadas cada uma em um béquer e adicionada água destilada até cobrir as amostras (Figura 12), deixando-as imersas por um período de 24 horas. 0 restante do material foi utilizado para obtenção do teor de umidade conforme descrito em 3.1.3.

Decorrido o prazo, a amostra a ser ensaiada foi transferida para o copo de dispersão e submetida a ação do aparelho por 15 minutos. Então, transferida com o auxílio de um funil de vidro para um picnômetro de $500 \mathrm{~m}^{3}$, previamente calibrado, e aplicado vácuo (Figura 18), a fim de se eliminar o ar contido entre as partículas, que interferem na massa específica de um material analisado. Ao aplicar o vácuo, foi levemente agitado o picnômetro em intervalos regulares para facilitar a expulsão do ar entre as partículas.

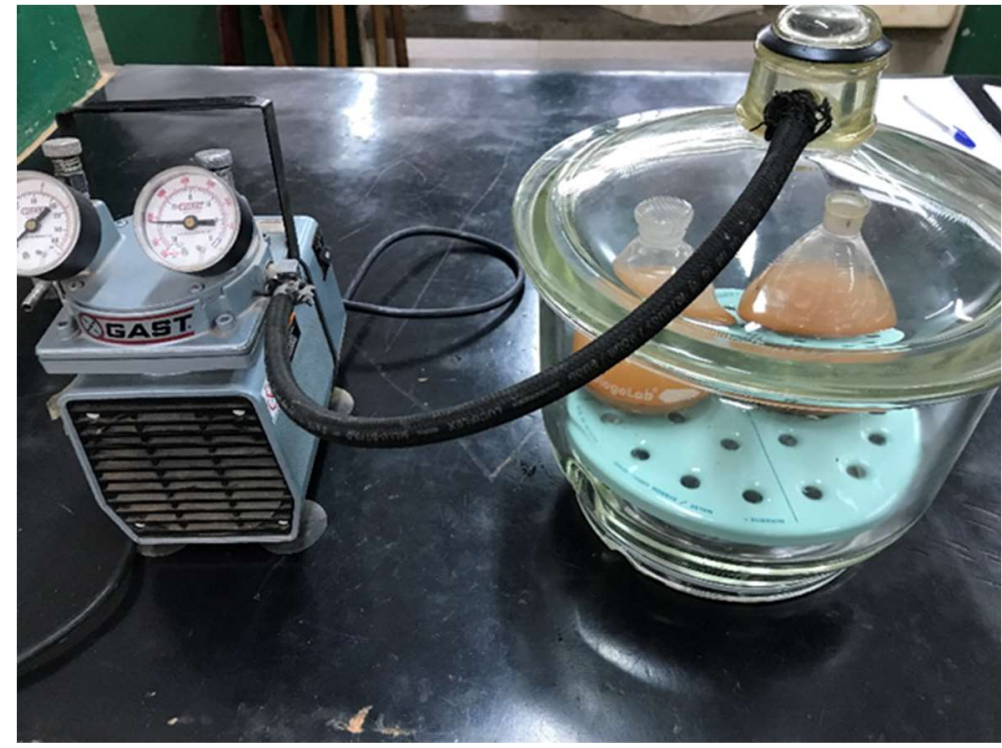

Figura 12: Aplicação de vácuo aos picnômetros com amostra de taipa.

Passados os 15 minutos, foi completado o volume do picnômetro até a metade com água destilada e aplicado novamente o processo de vácuo por 15 minutos. Em seguida foi completado o volume do picnômetro até $1 \mathrm{~cm}$ abaixo de sua marca e submetido uma última vez ao vácuo. Com auxílio de uma pipeta, seu volume foi completado com água destilada após um certo tempo em descanso, para que sua temperatura se equilibre à do ambiente, evitando alterações de massa e volume.

O picnômetro foi então cuidadosamente seco em sua parte externa e levado à balança de precisão, determinando-se a massa do conjunto, anotada como M2, e em seguida sua temperatura, anotada como T.

O cálculo do valor da massa específica dos grãos da porção passante na peneira de $4,8 \mathrm{~mm}$ é realizado pela Equação 10.

$$
\rho_{s}=\frac{\frac{M_{1} \times 100}{(100+w)}}{\left[\frac{M_{1} \times 100}{(100+w)]+M_{3}-M_{2}}\right.} \times \rho_{w(T)} \quad \text { (Equação 10) }
$$

M2: é a massa do picnômetro ou balão volumétrico + solo + água, à temperatura T de ensaio; M3: é a massa do picnômetro ou balão volumétrico cheio de água até a marca de referência, à temperatura $T$ de ensaio; w: é a umidade inicial da amostra; 
$\rho w(T)$ : é a massa específica da água à temperatura $T$ do ensaio, de acordo com a Tabela A.1 disponível no Anexo $A$ da NBR 6458 (ABNT, 2016).

É possível também se calcular a massa específica dos grãos de solo referente as porções passantes e retidas na peneira de 4,8 mm utilizando-se a Equação 11.

$$
\rho_{s}=\frac{\rho_{s p} \times \rho_{s r}}{\rho_{s p} \times M_{2}+\rho_{s r} \times M_{1}} \times 100
$$

Em que:

ps: é a massa específica dos grãos 3 do solo contendo frações passada e retida na peneira de 4,8 mm, expressa em gramas por centímetro cúbico $\left(\mathrm{g} / \mathrm{cm}^{3}\right)$; psp: é a massa específica dos grãos de solo que passam pela peneira de 4,8 $\mathrm{mm}$, expressa em gramas por centímetro cúbico $\left(\mathrm{g} / \mathrm{cm}^{3}\right)$; psr: é a massa específica de grãos de pedregulho retidos na peneira de 4,8 mm, expressa em gramas por centímetro cúbico $\left(\mathrm{g} / \mathrm{cm}^{3}\right)$;

M1: é a porcentagem em massa, da fração da amostra que passa na peneira de $4,8 \mathrm{~mm}$; M2: é a porcentagem em massa, da fração da amostra retida na peneira de $4,8 \mathrm{~mm}$.

\section{Determinação do teor de acidez do solo}

A norma técnica disponibilizada no catálogo vigente a ABNT para determinação do teor de acidez (pH) do solo é a NBR 9252 (ABNT, 2016). Contudo, optou-se por abrir mão da metodologia proposta em vista da indisponibilidade do equipamento centrifugador, tanto nos laboratórios do DACC/IFMT Campus Coronel Octayde Jorge da Silva quanto no laboratório de solos da FAET/UFMT Campus Cuiabá, e da ausência de informações por parte da norma quanto ao preparo dos reagentes necessários no ensaio, levantando uma série de dúvidas que poderiam comprometer os resultados.

Como alternativa, buscou-se apoio no Manual de Métodos de Análise de Solo, publicado pela Embrapa Solos, 3ạ edição, 2017. Foi adotada então a metodologia aplicada no Capítulo 1 - pH do solo (2017).

O ensaio é realizado a partir de uma amostra TFSA (Terra Fina Seca ao Ar). Portanto as amostras de taipa e adobe foram preparadas conforme a metodologia utilizada pela NBR 6457 (ABNT, 2016), descrita em 3.1.1, e passadas na peneira de 2,00 mm. Também foi realizada, por recomendação no manual, a calibragem do potenciômetro antes de se iniciar o ensaio, com auxílio das soluções-padrão pH 4,00 e pH 7,00.

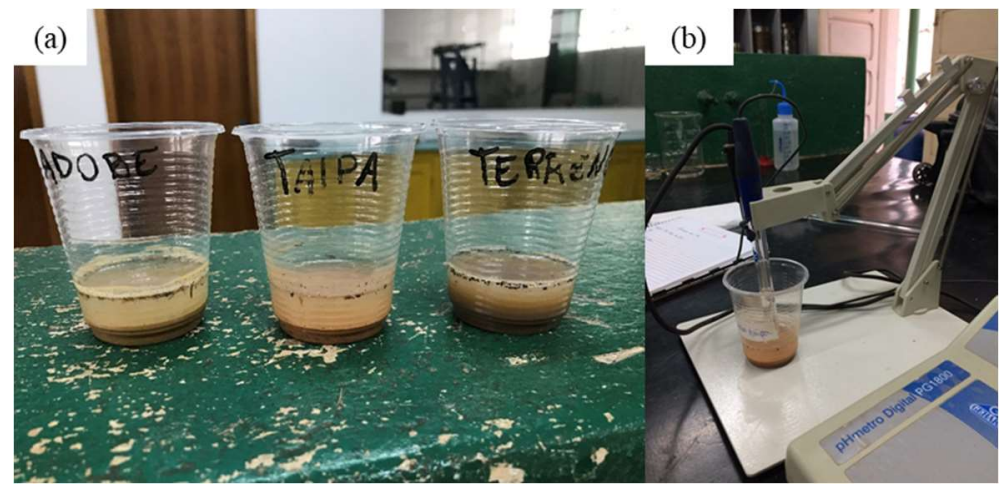

Figura 13: Amostras de taipa e adobe, retidas a frente e passantes ao fundo na peneira de 4,8 mm (a), submersas em água destilada; Amostra do terreno natural submersa em água destilada (b).

Foram reservadas cerca de $10 \mathrm{~g}$ de cada amostra preparada em um béquer e acrescido de $25 \mathrm{ml}$ de água destilada e $25 \mathrm{ml}$ de solução salina (preparada conforme descrito no método). As amostras foram agitadas cuidadosamente e deixadas em repouso por 1 hora (Figura 13a). Após o prazo agitou-se novamente 
as amostras e pode proceder a leitura de cada uma no potenciômetro, mergulhando os eletrodos na suspensão, conforme a Figura 13b. Os resultados são expressos diretamente pelo potenciômetro.

\section{Análise do material do desabamento}

Devido às más condições de conservação da Casa de Bem Bem, conforme já expostas no início do presente trabalho, e os consequentes desabamentos, o material pertencente às alvenarias de taipa e adobe originais encontram-se em partes desmoronadas, como pode-se observar nas Figuras 1 e 2, e algumas das paredes encontram-se em situação crítica (Figura 14), exigindo sua demolição por questões de segurança. Sendo assim, surge a oportunidade de reutilizar este mesmo material, como uma das vantagens do método construtivo com terra crua.

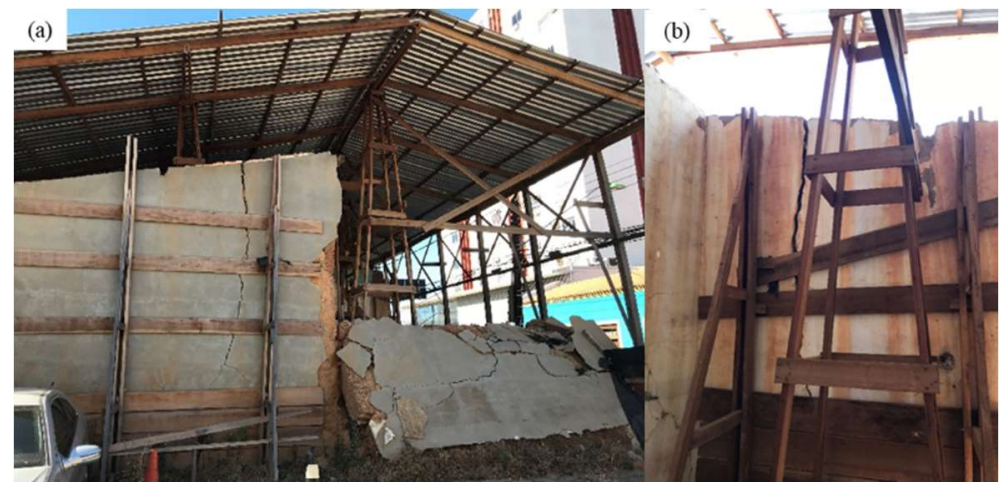

Figura 14: Amostras de (a) taipa e adobe, retidas a frente e passantes ao fundo na peneira de 4,8 mm, submersas em água destilada. (b) amostra do terreno natural submersa em água destilada.

Contudo, este material precisa ser analisado quanto a sua qualidade para reutilização, devido à presença de elementos indesejados, tal como resíduos de concreto e argamassa, empregados em intervenções de obras realizadas no local anteriormente. Para isto, será realizada uma visita ao local da obra para avaliação visual das condições de armazenamento dos materiais e avaliação visual quanto a presença de resíduos de construção e outros materiais indesejados e avaliado também os resultados dos ensaios de determinação dos Limites de Atterberg das amostras de adobe e de taipa.

\section{RESULTADOS E DISCUSSÃO}

Os resultados das análises dos materiais propostos no item 3.1 seguem de suas discussões por ensaio. Em seguida, análise da atual condição de aproveitamento do material proveniente do desmoronamento das alvenarias da edificação.

\section{Análise granulométrica}

Os resultados da análise granulométrica, por peneiramento e sedimentação, das amostras de adobe, de taipa e do terreno da Casa de Bem Bem são expressos nas curvas granulométricas da Figura 15 e um resumo das frações no Tabela 1. 


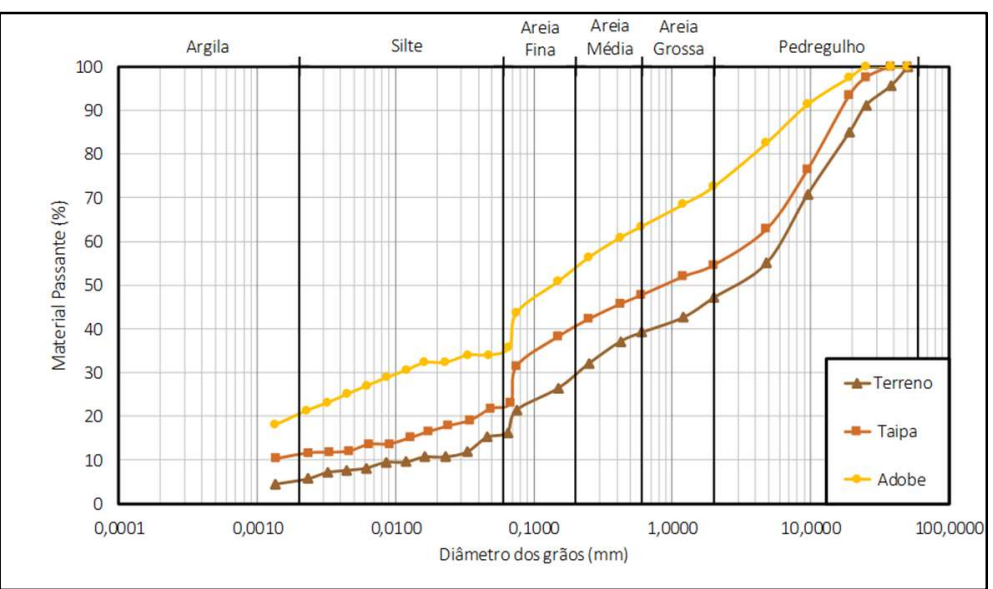

Figura 15: Curvas granulométricas das amostras de adobe, de taipa e do terreno natural.

Tabela 1: Resumo da distribuição granulométrica das amostras de adobe, de taipa e do terreno natural.

\begin{tabular}{cccc}
\hline Fração & Adobe & Taipa & Terreno \\
\hline Pedregulho (\%) & 27,45 & 45,42 & 52,80 \\
Areia Grossa (\%) & 9,15 & 6,91 & 8,00 \\
Areia Média (\%) & 12,54 & 9,51 & 12,75 \\
Areia Fina (\%) & 16,90 & 16,56 & 11,26 \\
Silte (\%) & 12,72 & 10,09 & 9,50 \\
Argila (\%) & 21,23 & 11,50 & 5,69 \\
\hline
\end{tabular}

A curva de distribuição granulométrica referente a amostra de terreno natural indica maior presença da fração de pedregulhos que as demais amostras, condizente com o tipo de solo superficial, em que ocorre a lavagem das partículas finas desta camada pelo escoamento das águas superficiais. Já as curvas das amostras de adobe e de taipa apresentam quantidade levemente superior das partículas menores, não afastando a hipótese de similaridade dos solos, mas sim indicando um possível processo de peneiramento aplicado no material para a execução das alvenarias de adobe e de taipa do patrimônio histórico, como usualmente empregado nos métodos executivos baseados em terra crua, segundo Minke (2015), para eliminar as partículas maiores, principalmente em adobes devido as suas fôrmas menores.

É possível observar ainda na Figura 15 uma grande proximidade das distribuições granulométricas das amostras de taipa e do terreno natural, bem como sua enorme semelhança de curvatura, e um pequeno distanciamento da distribuição da amostra de adobe. Contudo, esta última ainda apresenta certa semelhança quanto à forma se comparada as demais, apesar de não apresentar partículas superiores ao diâmetro de 19 $\mathrm{mm}$.

\section{Limites de Atterberg}

A Figura 16 apresenta as curvas de tendência dos pontos obtidos nos ensaios de determinação do Limite de Liquidez (WL) das amostras e o Tabela 2 apresenta os resultados da determinação dos Limites de Liquidez, Plasticidade (WP) e Índice de Plasticidade (IP).

Na Figura 16 é possível observar além da proximidade das linhas de tendência, suas inclinações são aproximadamente iguais, resultando em valores de teor de umidade para 25 golpes com pouca variação entre os três materiais. Ao analisar o Tabela 2, os valores determinados para o limite de plasticidade também pouco diferem entre as amostras, ao analisar, indicando um semelhante regime de plasticidade entre os materiais. Entretanto, os valores para o índice de plasticidade apresentam variações maiores, indicando um 
patamar de umidade ideal para compactação menor que os demais, característica que indica também uma maior habilidade na concepção das alvenarias em taipa da Casa de Bem Bem. O terreno natural apresenta um valor intermediário às amostras, assim estando próximo as duas, e indicando sua possível utilização.

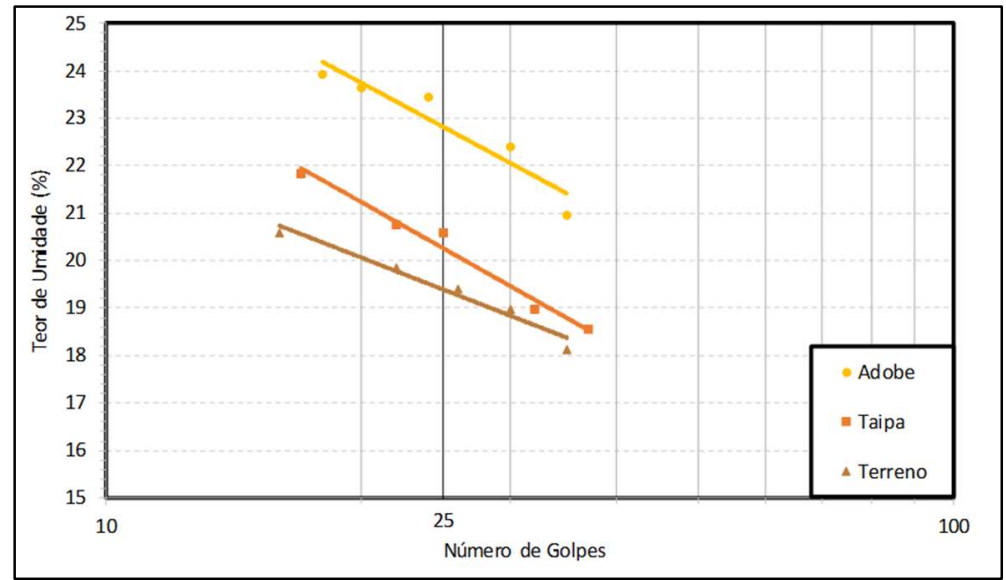

Figura 16: Curvas granulométricas das amostras de adobe, de taipa e do terreno natural.

Tabela 2: Limites de Atterberg das amostras de adobe, de taipa e do terreno natural.

\begin{tabular}{cccc}
\hline & Adobe & Taipa & Terreno \\
\hline WL (\%) & 22,8 & 20,3 & 19,4 \\
WP (\%) & 17,2 & 18,6 & 15,9 \\
IP (\%) & 5,6 & 1,7 & 3,5 \\
\hline
\end{tabular}

Cabe ressaltar a utilização de uma casa decimal na expressão dos resultados do Tabela 3, em vez dos números inteiros recomendados pela NBR 6459 (ABNT, 2016), devido a conferir maior significância neste caso. Outra alteração pertinente se fez nos eixos do gráfico representado na Figura 16, onde a NBR 7180 (ABNT, 2016) recomenda a disposição do Número de Golpes no eixo das ordenadas, em escala logarítmica, e o Teor de Umidade nas abscissas, fugindo do usual a publicações consultadas.

\section{Massa específica e absorção de água}

Os resultados dos ensaios para determinação da massa específica ( $\rho s)$, massa específica da fração passante ( $\rho s p)$ e da fração retida ( $\rho s r)$ na peneira de \#4,8 mm, massa específica aparente ( $\rho$ ap(s)) e absorção de água (Aa) encontram-se na Tabela 3.

Tabela 3: Massa específica e absorção de água.

\begin{tabular}{|c|c|c|c|}
\hline & Adobe & Taipa & Terreno \\
\hline$A_{a(\%)}$ & 2,74 & 2,41 & 1,61 \\
\hline$\rho_{\mathrm{ap}(\mathrm{s})}\left(\mathrm{g} / \mathrm{cm}^{3}\right)$ & 2,517 & 2,502 & 2,574 \\
\hline$P_{s r}\left(\mathrm{~g} / \mathrm{cm}^{3}\right)$ & 2,704 & 2,664 & 2,644 \\
\hline$\rho_{s p}\left(g / \mathrm{cm}^{3}\right)$ & 2,487 & 2,482 & 2,569 \\
\hline$\rho_{s}\left(\mathrm{~g} / \mathrm{cm}^{3}\right)$ & 2,646 & 2,619 & 2,606 \\
\hline
\end{tabular}

Comparando primeiramente os resultados das massas específicas, em diferentes condições de análise, observa-se pequenas disparidades, em geral variação na segunda casa decimal, como é o caso do valor final de $\rho s$, que engloba a massa especifica das porções retidas e passantes em sua definição. Esta pequena variação pode ser oriunda de possíveis materiais adicionados ao solo para sua utilização nas alvenarias, como característico dos métodos segundo Minke (2015) e Santiago (2001). 


\section{Teor de acidez (PH)}

Os teores de acidez $(\mathrm{pH})$ obtidos para as amostras de adobe, taipa e do terreno encontram-se na Tabela 4.

Tabela 4: Massa específica e absorção de água.

\begin{tabular}{cccc}
\hline & Adobe & Taipa & Terreno \\
pH & 5,64 & 6,75 & 7,73 \\
\hline
\end{tabular}

Os resultados apresentam grande variação entre si, sendo então as amostras de taipa e do terreno natural classificados, conforme a norma da EMBRAPA, como próximas a neutralidade e a amostra de adobe de acidez moderada.

\section{Análise do material do desabamento}

No dia 16 de outubro de 2019 foi realizada nova visita à Casa de Bem Bem, para avaliação das condições de reaproveitamento do solo utilizado nas alvenarias originais. Nesta data, as obras emergenciais para preservação do patrimônio histórico já haviam se iniciado e apresentavam grande avanço. Foi construída uma cobertura provisória (Figura 17) para estocagem dos materiais provenientes do desmoronamento das alvenarias de adobe (Figura 18a) e de taipa (Figura 18b). Em análise visual, não foi possível identificar presença de resíduos ou materiais indesejados.

Conforme discutido no item 4.2, os ensaios para determinação dos Limites de Atterberg apresentaram limites bem definidos, apesar de um pequeno patamar de teor de umidade ideal para compactação na amostra de taipa, mas ainda sim atendendo às necessidades para execução da alvenaria novamente.

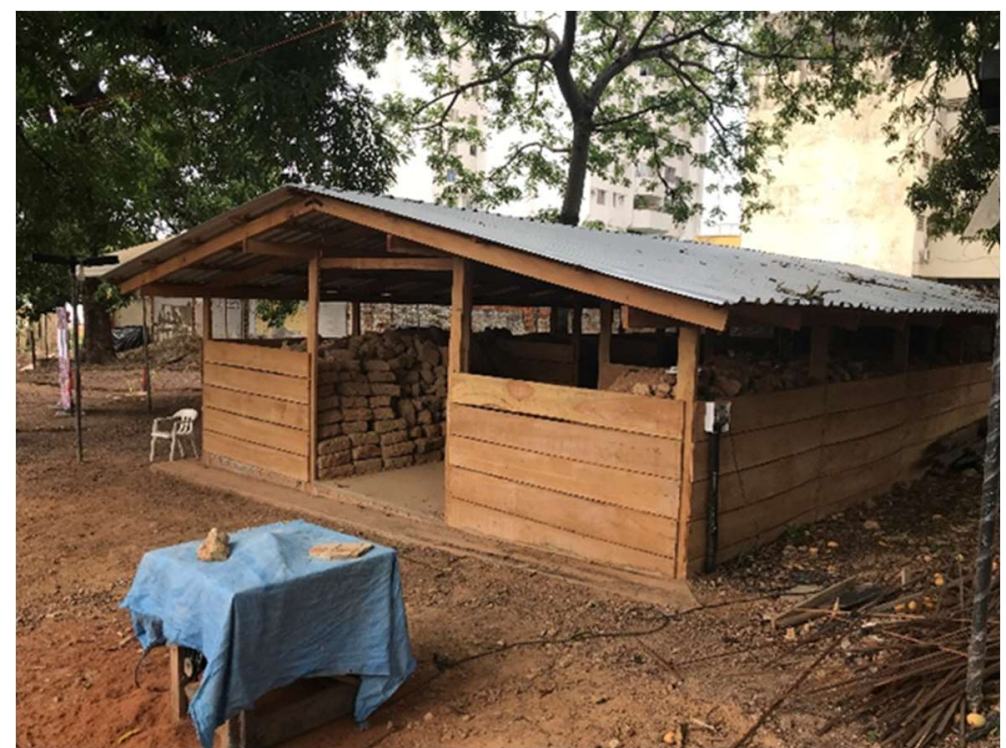

Figura 17: Instalação provisória para estocagem dos materiais do desabamento. 


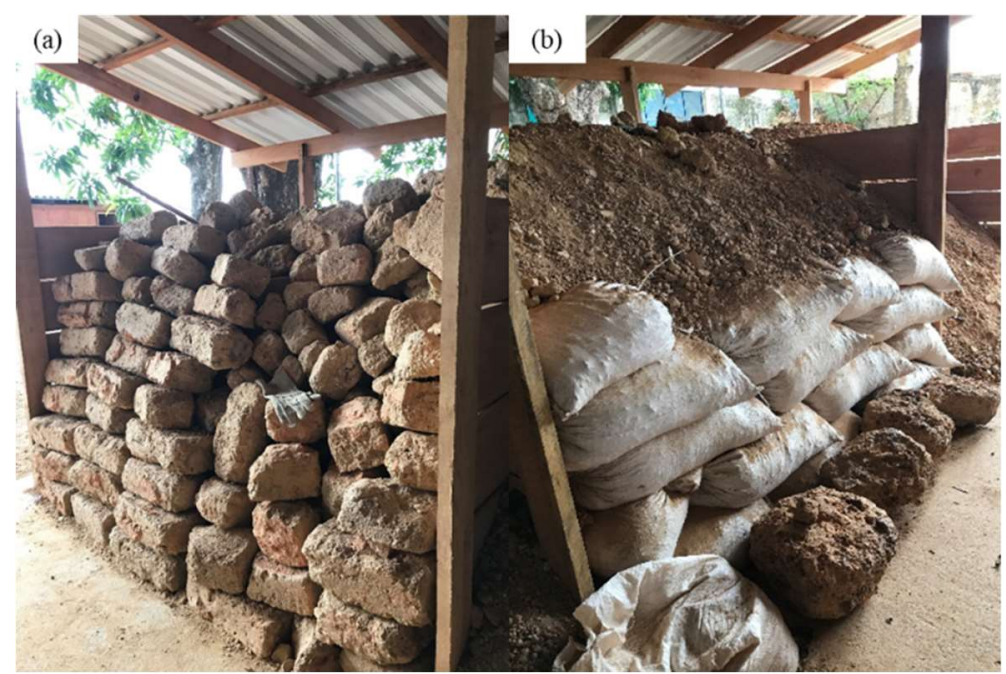

Figura 18: Estocagem dos materiais de desabamento das alvenarias de adobe (a) e taipa(b)

\section{CONCLUSÕES}

Em tempos marcados por construções em materiais industriais, como tijolo cerâmico, concreto e aço, o estudo das artes vernaculares toma folego com um crescente interesse em todo o mundo, como afirma Minke (2015), respondendo à arquitetura tanto sustentável quanto de baixo custo, uma vez que o material é encontrado em abundancia e utilizado em sua forma mais natural: a terra crua.

Apesar de nenhum livro de teoria ser capaz de substituir a experiência prática de construir com terra (MINKE, 2015), o emprego do método cientifico só tem a contribuir para o processo construtivo, ainda mais quando se trata de um assunto delicado como o restauro de um patrimônio histórico. Neste âmbito, o presente estudo buscou na comparação das amostras de adobe, de taipa e do terreno natural coletado no quintal do casarão tombado em questão, a Casa de Bem Bem, a semelhança e aplicabilidade na execução do restauro das alvenarias danificadas.

Diante dos resultados expostos e discutidos no item anterior, pode-se concluir que, muito provavelmente, a matéria prima utilizada na construção original do patrimônio foi coletada no próprio terreno, como de costume do método executivo segundo a literatura de Minke (2015), Santiago (2001), Torgal et al. (2009) e Neves et al. (2011). Contudo, as pequenas disparidades observadas indicam que o material recebeu um preparo anterior: peneiramento, sendo o adobe passado em uma peneira ainda menor que a taipa, uma vez que não apresenta partículas superiores ao diâmetro de 19 mm, também condizente já que sua fôrma é consideravelmente menor, justificando seu maior distanciamento nas curvas granulométricas. O menor teor de argila presente no terreno natural também o torna ideal para utilização em construções vernaculares, evitando-se o aparecimento de fissuras por retração, conforme aponta Torgal et al. (2009).

Já os ensaios de teor de acidez, se mostraram pouco conclusivos, apresentando grande variação nas amostras de adobe. Esta pode ser oriunda da adição de diversos materiais no processo executivo ou a exposição a demais fatores que alterem seu pH ao longo do tempo de utilização, necessitando de estudos aprofundados nesta questão. Porém, o pH encontrado na amostra do terreno natural de mostrou de caráter mais básico, indicado por Minke (2015) como ideal para utilização em alvenarias, prevenindo a proliferação 
de fungos.

Os resultados dos ensaios de massa específica concordam para uma grande semelhança entre as amostras, corroborando com a hipótese, e ainda a verificação de absorção de água, juntamente com os Limites de Atterberg verificados apontam o terreno natural do quintal do casarão tombado como adequados à moldagem de novas alvenarias, necessitando apenas da remoção de partículas maiores, empregando-se um simples peneiramento. Bem como também o material proveniente do desabamento das alvenarias originais se mostrou em boas condições para seu reuso.

Como continuidade desta pesquisa, sugere-se o estudo e a execução de amostras de paredes de taipa, definindo a melhor forma de compactação, as dimensões das fôrmas, dos pilões e a espessura das camadas.

A literatura também aponta a incorporação de outros materiais à terra crua, como folhas secas e palha na mistura para adobe e sangue ou fezes de animais na mistura para taipa (MINKE, 2015). Para um resultado mais conclusivo a respeito da presença destes materiais, indica-se a realização de ensaio de teor de matéria orgânica em estudos futuros, bem como a comparação e estudo de solo do terreno natural mais profundo, eliminando os $50 \mathrm{~cm}$ superficiais, de forma a obter horizontes com menor teor de matéria orgânica.

Como tema de nova pesquisa, quanto ao ensaio de granulometria com sedimentação segundo a NBR 7181 (ABNT, 2016), indica-se um estudo mais detalhado na metodologia de análise dos resultados dos diâmetros referentes a transição entre o método seco e o inundado (peneiramento seco e sedimentação), uma vez que as condições de umidade das partículas resultam em inchamento e acabam por interferir na definição de seu diâmetro, fato observado com uma queda brusca nas curvas granulométricas entre os diâmetros de 0,075 e 0,060 $\mathrm{mm}$.

\section{REFERÊNCIAS}

ABNT. Associação Brasileira de Normas Técnicas. NBR 6457: Amostras de solo. Preparação para ensaios de compactação e ensaios de caracterização. Rio de Janeiro: ABNT, 2016.

ABNT. Associação Brasileira de Normas Técnicas. NBR 6458: Grãos de pedregulho retidos na peneira de abertura $4,8 \mathrm{~mm}$ Determinação da massa específica, da massa específica aparente e da absorção de água. Rio de Janeiro: ABNT, 2016.

ABNT. Associação Brasileira de Normas Técnicas. NBR 6459: Solo. Determinação do limite de liquidez. Rio de Janeiro: ABNT, 2016.

ABNT. Associação Brasileira de Normas Técnicas. NBR 7180: Solo. Determinação do limite de plasticidade. Rio de Janeiro: ABNT, 2016

ABNT. Associação Brasileira de Normas Técnicas. NBR 7181: Solo. Análise granulométrica. Rio de Janeiro: ABNT, 2016.
ABNT. Associação Brasileira de Normas Técnicas. NBR 9252: Solo. Determinação do grau de acidez. Rio de Janeiro: ABNT, 2016.

MINKE, G.. Manual de construção com terra: uma arquitetura sustentável. São Paulo: B4, 2015.

NEVES, C.; OBEDE, B. F.. Técnicas de construção com terra. Bauru: UNESP, 2011.

SANTIAGO, C. C.. O solo como material de construção. 2 ed. Salvador: EDUFBA, 2001.

STEIN, K.. Com sinais de abandono, Casa de Bem Bem desaba 2 vezes em um ano. MIDIANEWS, 2018.

TORGAL, F. P.; EIRES, R. M. G.; JALALI, S.. Construção em terra. Guimarães: Universidade do Minho, 2009.

A CBPC - Companhia Brasileira de Produção Científica (CNPJ: 11.221.422/0001-03) detém os direitos materiais desta publicação. Os direitos referem-se à publicação do trabalho em qualquer parte do mundo, incluindo os direitos às renovações, expansões e disseminações da contribuição, bem como outros direitos subsidiários. Todos os trabalhos publicados eletronicamente poderão posteriormente ser publicados em coletâneas impressas sob coordenação da Sustenere Publishing, da Companhia Brasileira de Produção Científica e seus parceiros autorizados. Os (as) autores (as) preservam os direitos autorais, mas não têm permissão para a publicação da contribuição em outro meio, impresso ou digital, em português ou em tradução. 